\title{
Pyrolysis of Solid Waste for Bio-Oil and Char Production in Refugees' Camp: A Case Study
}

\author{
Ebtihal A. AlDayyat ${ }^{1}$, Motasem N. Saidan ${ }^{1, *}$, Zayed Al-Hamamre ${ }^{1}$, Mohammad Al-Addous ${ }^{2} \mathbb{D}$ and \\ Malek Alkasrawi ${ }^{3}$ \\ 1 Chemical Engineering Department, School of Engineering, The University of Jordan, Amman 11942, Jordan; \\ AlDayyat@ju.edu.jo (E.A.A.); z.hamamre@ju.edu.jo (Z.A.-H.) \\ 2 Energy Engineering Department, School of Natural Resources Engineering and Management, \\ German Jordanian University, P.O. Box 35247, Amman 11180, Jordan; mohammad.addous@gju.edu.jo \\ 3 Department of PS and Chemical Engineering, University of Wisconsin Stevens Point, \\ Stevens Point, WI 54481, USA; alkasraw@uwp.edu \\ * Correspondence: malkasra@uwsp.edu or m.saidan@ju.edu.jo
}

check for updates

Citation: AlDayyat, E.A.; Saidan, M.N.; Al-Hamamre, Z.; Al-Addous, M.; Alkasrawi, M. Pyrolysis of Solid Waste for Bio-Oil and Char Production in Refugees' Camp: A Case Study. Energies 2021, 14, 3861. https://doi.org/10.3390/en14133861

Academic Editor: Ricardo J. Bessa

Received: 4 May 2021

Accepted: 21 June 2021

Published: 27 June 2021

Publisher's Note: MDPI stays neutral with regard to jurisdictional claims in published maps and institutional affiliations.

Copyright: (c) 2021 by the authors. Licensee MDPI, Basel, Switzerland. This article is an open access article distributed under the terms and conditions of the Creative Commons Attribution (CC BY) license (https:/ / creativecommons.org/licenses/by/ $4.0 /)$.

\begin{abstract}
The current research focuses on assessing the potential of municipal solid waste (MSW) conversion into biofuel using pyrolysis process. The MSW samples were taken from Zaatari Syrian Refugee Camp. The physical and chemical characteristics of MSW were studied using proximate and elemental analysis. The results showed that moisture content of MSW is $32.3 \%$, volatile matter (VM) is $67.99 \%$, fixed carbon (FC) content is $5.46 \%$, and ash content is $24.33 \%$. The chemical analysis was conducted using CHNS analyzer and found that the percentage of elements contents: $46 \%$ Carbon (C) content, $12 \%$ Hydrogen $\left(\mathrm{H}_{2}\right), 2 \%$ Nitrogen $\left(\mathrm{N}_{2}\right)$, 44\% Oxygen $\left(\mathrm{O}_{2}\right)$, and higher heat value (HHV) is $26.14 \mathrm{MJ} / \mathrm{kg}$. The MSW pyrolysis was conducted using tubular fluidized bed reactor (FBR) under inert gas (Nitrogen) at $500{ }^{\circ} \mathrm{C}$ with $20^{\circ} \mathrm{C} / \mathrm{min}$ heating rate and using average particles size $5-10 \mathrm{~mm}$. The products of MSW pyrolysis reaction were: pyrolytic liquid, solid char, and gaseous mixture. The pyrolytic oil and residual char were analyzed using Elemental Analyzer and Fourier Transform Infrared Spectroscopy (FTIR). The results of FTIR showed that oil product has considerable amounts of alkenes, alkanes, and carbonyl groups due to high organic compounds contents in MSW. The elemental analysis results showed that oil product content consists of $55 \% \mathrm{C}, 37 \% \mathrm{O}_{2}$, and the HHV is $20.8 \mathrm{MJ} / \mathrm{kg}$. The elemental analysis of biochar showed that biochar content consists of $47 \% \mathrm{C}, 49 \%$ $\mathrm{O}_{2}$, and $\mathrm{HHV}$ is $11.5 \mathrm{MJ} / \mathrm{kg}$. Further research is recommended to study the effects of parameters as reactor types and operating conditions to assess the feasibility of MSW pyrolysis, in addition to the environmental impact study which is necessary to identify and predict the relevant environmental effects of this process.
\end{abstract}

Keywords: MSW; pyrolysis; bio-oil; char; refugee camp; Jordan

\section{Introduction}

The global energy demand is increasing as a result of an increasing world population as well as a dramatic increase of the world economy [1,2]. This created challenges with energy production, distribution, sustainability, and security. Renewable energy technologies played a role in providing an alternative energy supply and reducing the load on the energy demand $[3,4]$. The pyrolysis of MSW is a promising technology for converting the MSW to biofuels and chemicals. The pyrolysis process potentially can replace the traditional MSW incineration, providing a cleaner way for power production [5]. Implementation of pyrolysis for MSW cuts the emission of nitrogen oxides (NOx) and sulfuroxides $\left(\mathrm{SO}_{2}\right)$ as well as reduces the load for the landfill. Various pyrolysis investigations have been carried out on industrial wastes such as plastic, tires, and organic waste [6,7], and several reviews showed the technology is promising in terms of overall yield and conversion factor. The studies covered several technical aspects such as reactor configuration, residence time 
product recovery, and chemical characterization [5]. However, the major technical obstacle for the pyrolysis technology is the capital cost related to the construction materials and energy supply system.

Jordan is one of several countries suffering from shortages of energy and water due to many reasons but mainly the lack of natural resources such as fossil fuel. Jordan imports about $96 \%$ of energy supply from neighboring countries [8-10]. Jordan's population is increasing at a high rate, and the current population is 9.53 million inhabitants. Water consumption, demand, shortages, and treatment impose great challenges to the country [11-13]. Due to political and economic crises in the middle east region, Jordan welcomes several refugees with their families. The refugee's percentage reached $30 \%$ of the total population, and recent records showed $30 \%$ are registered officially as refugees. Syrians comprise $80 \%$ of refugees in Jordan living in major Jordanian cities while $20 \%$ inhabit in the Zaatari, Marjeeb al-Fahood, Cyber City, and Al-Azraq camps [14,15].

The criteria and regulations of solid waste management (SWM) services in Jordan has changed due to the sudden increase of refugees in the northern governorates of Jordan. The huge and sudden influx of Syrian refugees has overwhelmed the absorptive capacity of the host communities, and as the population grows, service delivery deteriorates, and the competition for resources intensifies, particularly in Northern part of Jordan [16-18].

Saidan, Drais, and Al-Manaseer [14] undertook a waste characterization and composition analysis of the waste disposal collected from various populated districts including the from several areas from Zaatari refugees' camp. The main target of the study categorized the waste in term of their physical and chemical properties and found the majority of the waste disposed at the landfill of Alhussaniat, Al-Mafraq [14]. Al-Addous, Saidan, Bdour, and Alnaief [19] evaluated the potential of household waste at refugee camps conversion into combined with wastewater sludge. The biogas generation data would help in developing waste utilization model in the camp and propose and improve the economic and lifestyle of people [20].

Pyrolysis process is based on a thermochemical decomposition of the organic biomass after heating it up to 400 to $550{ }^{\circ} \mathrm{C}$ with no presence of oxygen producing bio-oil, char, and synthesis gas [21]. The produced Bio-oil, which is a condensed vapor of mixture of organic chemicals with water, can be a vital fuel alternative in many static applications like boiler and diesel engines for power generations in the refugee camps [22]. Household food waste provides zero cost feedstock for various chemicals and energy production while solving the management burden [23]. The compositional analysis of household food waste is proteins, lipids carbohydrates, organic acids, and lignin [24]. Patel, Hrůzová, Rova, Christakopoulos, and Matsakas [25] reported that biofuels can lower greenhouse gas (GHG) emissions compared to traditional fossil fuels.

The pyrolysis and co-pyrolysis of mixture of wastes have drawn a wide awareness in current years [26]. However, proper selection of sustainable input materials and process conditions optimization are the significant prerequisite for their successful application $[22,27,28]$.

The main objective of the present study is to investigate the possibilities of converting MSW via a pyrolysis reactor and examine the quality of product output in the Zaatari Syrian refugees' camp. The liquid (bio-oil) and solid (char) products from pyrolysis are studied with respect to their chemical composition and calorific values. The study aims at providing sustainable solution of solid waste management combined with energy recovery via pyrolysis process.

\section{Materials and Methods}

\subsection{Study Site}

The Zaatari Refugee Camp was inaugurated summer of 2012 near Mafraq city, Jordan, to host Syrian refugees. The camp hosted roughly half a million Syrian refugees depending entirely on external support for their daily expenses. The camp has $24 \mathrm{k}$ established caravans and estimated 35 liters water requirement for each person [14]. 
The non-governmental organization took the responsibility to manage and coordinate the MSW by installing collection bins and dumpers inside the camp. Inside the camp, and on a regularly basis, $28-50$ tons of MSW are collected by contractors. The MSW is collected without any recycling activities and disposed as whole to the Al Ehsyniat landfill.

\subsection{Sample Preparation}

The samples used for the experiments in the present study were taken throughout the study activities of MSW composition determination, sampling, and manual sorting procedures conducted by Saidan, Drais, and Al-Manaseer [14] in Zaatari Syrian Refugee Camp, Jordan, between 19 November and 21 November 2015.

A representative MSW pile sample was obtained using the standard method of coning and quartering (SABS method). The average percentages of waste compositions of the $1 \mathrm{~kg}$ representative MSW sample are shown in Table 1. Subsequently, MSW samples were cut down into small pieces, chipped, and milled prior experiments.

Table 1. The average values of percentages for waste composition of $1 \mathrm{~kg}$ mixed MSW sample.

\begin{tabular}{cc}
\hline Material & Proportion (\%) \\
\hline Organic & 53.27 \\
Paper & 7.07 \\
Corrugated Cartoon & 8.68 \\
Textile & 2.47 \\
Hygienic textile & 6.00 \\
Film & 11.38 \\
PET & 2.60 \\
PE & 0.89 \\
PP & 0.24 \\
PS & 1.71 \\
Combustible & 5.68 \\
\hline Total & 100.00 \\
\hline
\end{tabular}

\subsection{MSW Characterization Method}

The characterization analysis of the raw materials is needed to identify the main properties that influence the pyrolysis as moisture content (MC), ash, volatile matter (VM), and higher heat value (HHV) which could be helpful for predicting the by-products characteristics.

The proximate analysis is carried out to identify the MC, ash, and VM. The sample was oven dried at $105^{\circ} \mathrm{C}$ to remove water content for $48 \mathrm{~h}$, and the percentage of water content is then calculated by evaluating the sample mass difference before and after drying. ASTM standard test method was used to determine VM and ash on a dry basis using TGA, while fixed carbon (FC) is determined by their difference.

Moisture content: The percentage weight difference is calculated using Equation (1) and recorded as percentage of MC of the sample.

$$
M C(w t . \%)=\frac{W_{0}-W_{1}}{W_{0}} \times 100 \%
$$

where $W_{0}$ : sample weight before heating and $W_{1}$ : weight of sample after drying. The moisture content is determined by the mass loss that sample undergoes after it has been heated up to $105^{\circ} \mathrm{C}$ for $48 \mathrm{~h}$.

Volatile matter: The VM of samples is the non-condensable and condensable vapor emitted after or during samples heating. The VM amount depends on the temperature to which sample is heated with the rate of heating can be found using Equation (2):

$$
V M(w t . \%)=\frac{W_{1}-W_{2}}{W_{1}} \times 100 \%
$$


where $\mathrm{W}_{2}$ is weight of sample after heating to $300^{\circ} \mathrm{C}$. The volatile matter content corresponds to the volatiles evolving between 110 and $285^{\circ} \mathrm{C}$, and in time duration between 5-10 min.

Ash content: Ash is the inorganic solid residue left after complete incineration of the sample. The ash content is calculated using Equation (3):

$$
\operatorname{Ash}(w t . \%)=\frac{W_{2}-W_{3}}{W_{2}} \times 100 \%
$$

where $\mathrm{W}_{3}$ is sample weight after heating at temperature exceeds $500{ }^{\circ} \mathrm{C}$. The ash content is the final content after process completion.

Fixed carbon: FC is the remaining solid carbon fraction sample after de-volatilization process. It is simply can be determined by mass balance on the experiments sample as in Equation (4):

$$
F C=100-M C-V M-A s h
$$

The FC content is the amount of solid remaining after loss of moisture and volatile contents and calculated by the difference after subtracting the residue content after (ash). The temperature range corresponding to the FC content is between 285 and $480{ }^{\circ} \mathrm{C}$.

The elemental analysis and the calorific values are determined empirically using the results of proximate analysis and by Equations (5)-(9):

$$
\begin{gathered}
C=0.97 F C+0.7(V M-0.1 A s h)-M C(0.6-0.01 M C) \\
H=0.036 \times F C+0.086 \times(V M-0.1 \times A s h)-0.0035 \times M C^{2}(0.6-0.02 \times M C) \\
N_{2}=2.10-0.020 \times V M \\
O_{2}=100-(C+H+N+A s h) \\
H H V=4.18 \times\left(78.4 \times C+241.3 \times\left(H \times \frac{O}{8}\right)\right)+22.1 \times S
\end{gathered}
$$

The calorific values (HHV and LHV) of char residues can be calculated using Dulongs formula in Equations (9) and (10):

$$
L H V=4.18 \times(94.19 \times C-0.5501-52.14 \times H)
$$

Elemental analysis: The elemental analysis is used to determine the weight mass fractions of major elements such as carbon, nitrogen, hydrogen, oxygen, and sulfur of the sample using EA CHNS analyzer (Model Euro EA, serial 8910) and based on (sulphanilamide) standard. The HHV is determined based on the experimental results of elemental analysis. The energy content is calculated using Dulong expressed by Equation (11)

$$
E(k J / k g)=337 \times C+1428 \times(H-O / 8)+9 \times S
$$

where $\mathrm{C}, \mathrm{H}, \mathrm{O}$, and $\mathrm{S}$ represent the mass fractions (\%) of non-mineral major elements (carbon, hydrogen, nitrogen, oxygen, and sulfur) found using the elemental analysis of material samples.

The yield and composition of the non-condensable gases and products evolved are a function of the temperature, pressure, and gas composition $\left(\mathrm{CO}, \mathrm{CO}_{2}, \mathrm{CH}_{4}\right.$, and $\left.\mathrm{H}_{2}\right)$ during the de-volatilization.

The basic functional groups of the bio-oil produced from MSW pyrolysis were analyzed by FTIR spectroscopy using Thermo Nicolet (NEXUS) 670 FTIR and tablet of potassium bromide $(\mathrm{KBr})$ at the Chemistry Department labs in the Faculty of Science.

\subsection{MSW Pyrolysis Setup: MSW Pyrolysis Sing Fluidized Bed Reactor}

In the current investigation, a lab scale fluidized bed reactor (FBR) was used with total volume of 2.4 L, Figure 1. The FBR is fabricated from stainless steel with length of $60 \mathrm{~cm}$ 
and $3.58 \mathrm{~cm}$ as internal radius. The reactor packed with $350 \mathrm{~g}$ inert sand with particle size less than $355 \mu \mathrm{m}$ and density of $1.876 \mathrm{~g} / \mathrm{cm}^{3}$. The nitrogen was flushed through the FBR through the inert sand while maintaining same working pressure. The feedstock of the MSW was fed at a density of $0.1 \mathrm{~g} / \mathrm{mL}$.

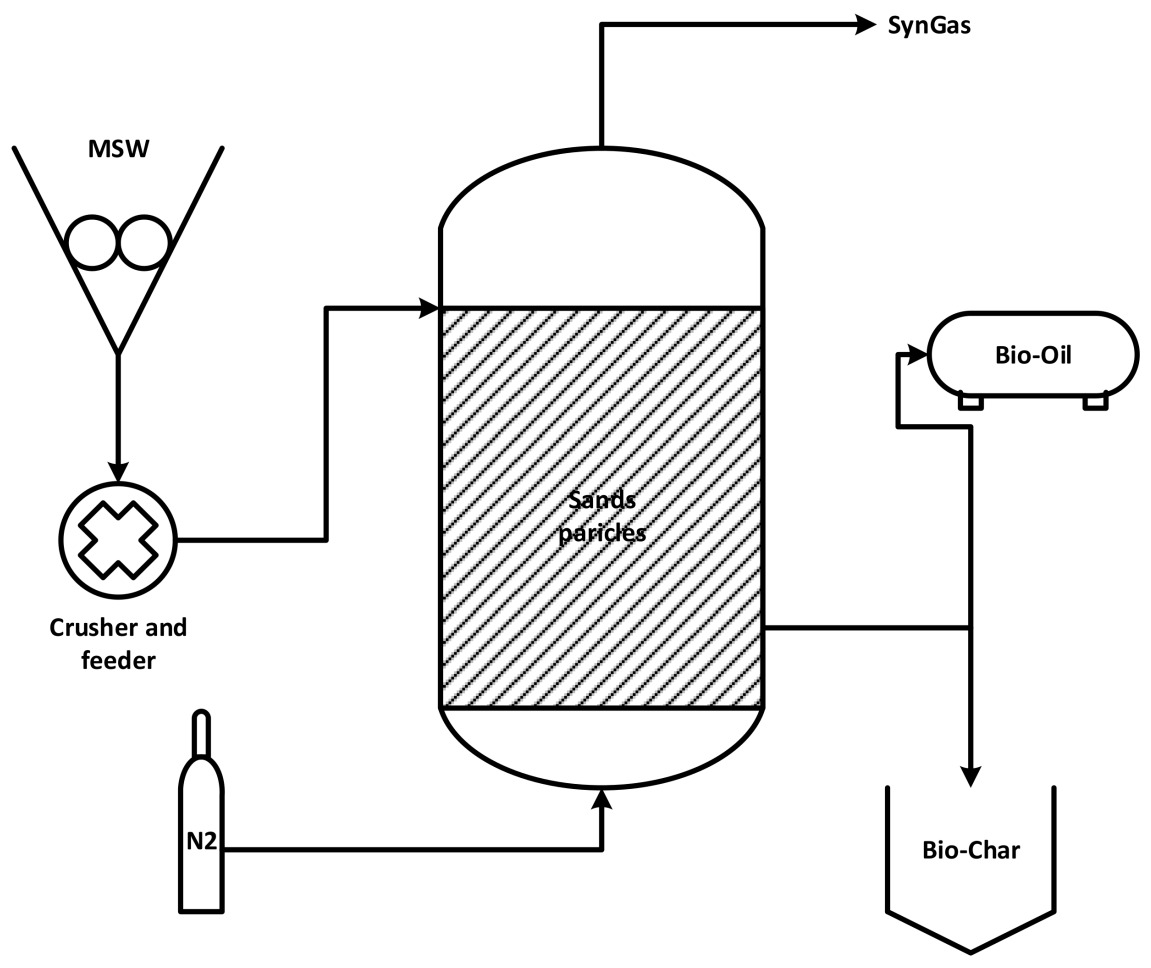

Figure 1. Setup and configuration of the fluized bed reactor.

The FBR pyrolysis system is a multiphase chemical reaction which consists of three main parts, which are feeder, reactor, and product collection. This reactor is heated to the temperature needed for experiment up to $500{ }^{\circ} \mathrm{C}$ using temperature controller (Eurotherm, Ser. No.6 ALDER). The temperature controller is used to fix the temperature at the required level. The reactor is heated via installing external electrical heater where the temperature is controlled and regulated by a thermocouple ( $\mathrm{Pt} / \mathrm{Pt} \mathrm{13 \%} \mathrm{Rh}$ thermocouple) inside the bed.

The feedstock of raw MSW was fed to the pyrolysis with total mass of $40 \mathrm{~g}$, and the average particles was measured at size $5 \mathrm{~mm}-10 \mathrm{~mm}$. The reactor was heated up gradually at a rate of $20^{\circ} \mathrm{C} / \mathrm{min}$ until it reached $500{ }^{\circ} \mathrm{C}$ as operating temperature. In order to provide oxygen-free reaction environment, nitrogen was flushed through the reactor at rate of $0.1 \mathrm{dm}^{3} / \mathrm{min}$. The liquid phase of the pyrolysis reaction collected in a separate bottle and stored at $0{ }^{\circ} \mathrm{C}$ prior any analysis. The yields calculation was based on a dry content of MSW without the dry ash content (daf).

The optimum operation parameters such temperature, flow rate, residence time, and particle size are applied to the experiment set-up [14]. The operating conditions are shown in Table 2. 
Table 2. The pyrolysis experiment operating conditions.

\begin{tabular}{|c|c|c|}
\hline \multicolumn{2}{|c|}{ Fluidized Bed Dimensions } & \multirow{2}{*}{$\frac{\text { Unit }}{\mathrm{cm}}$} \\
\hline Bed height $\left(\mathrm{H}_{\mathrm{bed}}\right)$ & 60 & \\
\hline Bed cross sectional area $\left(\mathrm{A}_{\mathrm{c}}\right)$ & 40.26 & $\mathrm{~cm}^{2}$ \\
\hline Particles volume $\left(\mathrm{V}_{\mathrm{p}}\right)$ & $6.98 \times 10^{-5}$ & $\mathrm{~cm}^{3}$ \\
\hline Particle surface area $\left(\mathrm{A}_{\mathrm{p}}\right)$ & 0.00819 & $\mathrm{~cm}^{2}$ \\
\hline $\begin{array}{l}\text { Minimum fluidization } \\
\text { velocity }\left(\mathrm{U}_{\mathrm{mf}}\right) *\end{array}$ & 5.36 & $\mathrm{~cm} / \mathrm{s}$ \\
\hline $\mathrm{N}_{2}$ (viscosity @500 ${ }^{\circ} \mathrm{C}$ ) & $\begin{array}{ll} & 3.421 \times 10^{-3} \\
\text { Reactor Operating Conditions }\end{array}$ & $\mathrm{g} / \mathrm{cm} . \mathrm{s}$ \\
\hline Temperature of reactor $(\mathrm{T})$ & 500 & ${ }^{\circ} \mathrm{C}$ \\
\hline Sample density $(\rho)$ & 0.1 & $\mathrm{~g} / \mathrm{mL}$ \\
\hline Sand density $(\rho)$ & 3 & $\mathrm{~g} / \mathrm{mL}$ \\
\hline Flow rate $(\mathrm{sfcm})$ & $1(28.32)$ & $1 / \mathrm{min}$ \\
\hline Residence time $(t) *$ & 11 & $\mathrm{~s}$ \\
\hline Pressure $(\mathrm{P})$ & 0.25 & bar \\
\hline
\end{tabular}

\section{Results and Discussions}

The dried MSW sample is weighed after drying at $105^{\circ} \mathrm{C}$ using oven for $48 \mathrm{~h}$, and the percentage of moisture content was found to be $32.3 \%$.

The results of proximate analysis are presented in Table 3. The proximate analysis results are used to determine empirically the elemental analysis and the calorific values using equations (5 to 10). The results obtained are compared to the results found in literature and showed a good agreement, as shown in Tables 3 and 4. During the pyrolysis process, the organic substances are converted into various forms. One of these forms is a condensable VM that enriches the bio-oil content. Table 3 shows that the MSW has high portions of VM and a low amount of FC. This shows the current MSW is a promising feedstock for pyrolysis. Table 4 shows good HHV compared to other solids fuel and relatively low LHV due to high moisture content. If the camp decided to scale up the process and manage the MSW via pyrolysis step, a heat recovery system is required to minimize the energy demand. Most likely, the camp will utilize the bio-oil as the main fuel for a boiler. Therefore, and to maximize the mount of the bio-oil, we recommend avoiding performing pyrolysis at a temperature higher than $550{ }^{\circ} \mathrm{C}$ since it favors the biochar over the bio-oil. The $\mathrm{H} / \mathrm{C}$ ratio in the feedstock impacted the yields of gas, bio-oil, and char [29]. The MSW contains low $\mathrm{H} / \mathrm{C}$ content, leading to yielding more char but reducing the tar yield in the pyrolysis. The $\mathrm{H} / \mathrm{C}$ ratio was reported to influence the formation of the cycling chemicals in the tar [29].

Table 3. Proximate analysis of the MSW samples based on dry basis with error less than $2 \%$.

\begin{tabular}{ccccc}
\hline $\begin{array}{c}\text { Heating Rate } \\
\left({ }^{\circ} \mathbf{C} / \text { min) }\right.\end{array}$ & M & VM & FC & Ash \\
\hline 10 & 1.95 & 66.70 & 6.34 & 25.02 \\
30 & 2.54 & 68.45 & 3.98 & 25.03 \\
50 & 2.17 & 68.82 & 6.08 & 22.93 \\
\hline
\end{tabular}

Table 4. MSW elemental analysis using proximate analysis with error less than $2 \%$ at different rates.

\begin{tabular}{ccccccc}
\hline Heating Rate $\left({ }^{\circ} \mathbf{C} / \mathbf{m i n}\right)$ & $\mathbf{C}$ & $\mathbf{H}$ & $\mathbf{N}_{\mathbf{2}}$ & $\mathbf{O}_{\mathbf{2}}$ & $\mathbf{H H V ~ ( k J / k g )} \mathbf{~ L H V ~ ( k J / k g )}$ \\
\hline 10 & 51.07 & 5.74 & 0.77 & 42.42 & $32,089.61$ & $18,855.07$ \\
30 & 50.01 & 5.80 & 0.73 & 25.02 & $25,538.03$ & $18,421.46$ \\
50 & 52.41 & 5.93 & 0.72 & 23.61 & $25,993.03$ & $19,339.46$ \\
MSW ultimate analysis (Luo et al., 2010 [30]) & 51.81 & 5.76 & 0.26 & 30.22 & 21,306 & - \\
\hline
\end{tabular}




\subsection{Elemental Analysis of MSW}

The elemental analysis was performed to MSW sample using CHNS elemental analyzer. Three MSW samples were analyzed each run. Figure 2a shows the MSW proposed sample. The results are listed Table 5. Accordingly, the chemical composition is characterized by $\mathrm{C}_{34.8} \mathrm{H}_{96.17} \mathrm{O}_{62.46} \mathrm{~N}$ formula.

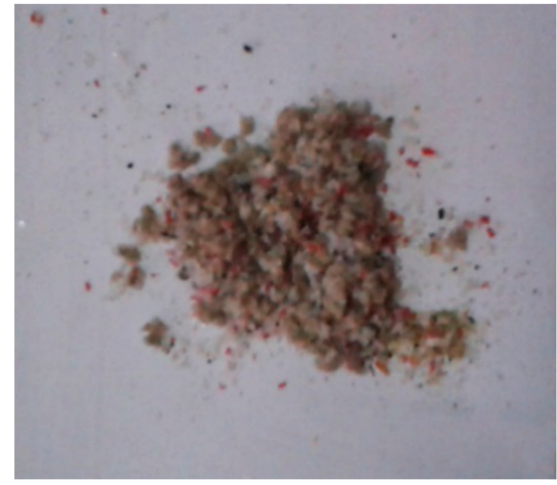

(a)

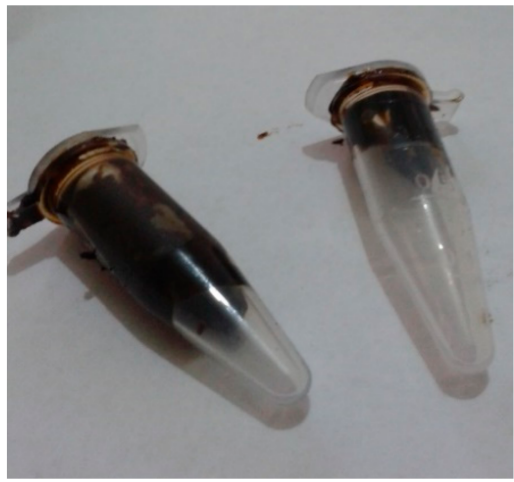

(b)

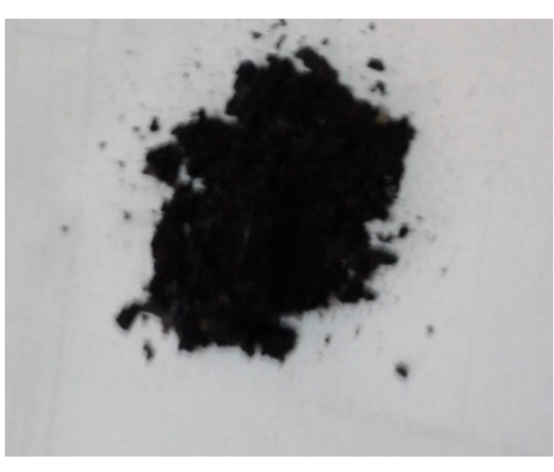

(c)

Figure 2. (a) MSW prepared sample, (b) The MSW biofuel samples, and (c) MSW biochar sample.

Table 5. Elemental analysis of MSW, bio-oil and char.

\begin{tabular}{cccc}
\hline \multirow{2}{*}{ Element } & \multicolumn{3}{c}{ Element Fraction (\%) } \\
\cline { 2 - 4 } & MSW (\%) & Bio-Oil (\%) & Char (\%) \\
\hline Carbon (C) & $46.8 \pm 0.93$ & $49.65 \pm 0.97$ & $42.84 \pm 1.78$ \\
Hydrogen (H) & $12.5 \pm 0.08$ & $6.12 \pm 2.49$ & $3.09 \pm 2.19$ \\
Oxygen (O) & $41.0 \pm 1.54$ & $41.62 \pm 1.73$ & $52.37 \pm 2.14$ \\
Nitrogen (N) & $1.55 \pm 0.29$ & $1.24 \pm 0.08$ & $0.98 \pm 0.85$ \\
Sulphur (S) & 0 & 0 & 0 \\
H/C & ND & $0.11 \pm 0.06$ & $0.07 \pm 0.05$ \\
O/C & ND & $0.69 \pm 0.24$ & $1.07 \pm 0.26$ \\
HHV (kJ/kg) & $25,825.93 \pm 148$ & $20,788.55 \pm 1821$ & $13,386.01 \pm 621$ \\
\hline
\end{tabular}

\subsection{Elemental Analysis of Biofuel}

The pyrolysis oil obtained from the experiment is brownish dark color with intense smell and very viscous. It converts into heavy and thick liquid after water vaporization, which was the reason behind tube clogging in the tube extensions at the reactor exit. The elemental analysis of biofuel (Figure 2b) produced from the MSW pyrolysis was performed using CHNS elemental analyzer.

The results are shown in Table 5, and the chemical composition is characterized by $\mathrm{C}_{52.133} \mathrm{H}_{34.54} \mathrm{O}_{26.23} \mathrm{~N}$ formula.

The elemental analysis of the biofuel shows that $\mathrm{O} / \mathrm{C}$ content is relatively high, which can be the reason for lower heating value of the biofuel, so it is important to deoxygenate the liquids by some upgrading technology. The heating value measurement was found to be $20.8 \mathrm{MJ} / \mathrm{kg}$, which is $45 \%$ lower than the calorific value of biodiesel. Table 5 shows no sulfur was detected despite the MSW might have sulfur from the protein content of the food. This might be due to formation of $\mathrm{SO}_{4}, \mathrm{SO}_{2}, \mathrm{COS}$, and $\mathrm{H}_{2} \mathrm{~S}$ during the reduction stage. Shao et al. 1994 [31] showed most of sulfur based-gases are formed during the coal pyrolysis. The average value of $\mathrm{H} / \mathrm{C}$ ratio in the bio-oil was 0.12 and indicated more aromatic compounds are formed; Table 5. By contrast, the average of $\mathrm{O} / \mathrm{C}$ ratio, 0.7 , was higher than $\mathrm{H} / \mathrm{C}$ ratio (0.12). This might be attributed to the formation of $\mathrm{C}-\mathrm{O}$ bonds. Bet et al. 2019 [32] provide a comprehensive analysis of the bio-oil pyrolysis showing that the hydroxyl group interacts with the aromatic ring to form aromatic $\mathrm{C}-\mathrm{O}$ bonds. 
Elemental analysis of biochar: The elemental analysis of biochar shown (Figure 2c) produced from the MSW pyrolysis was performed using CHNS elemental analyzer. The results are shown in Table 5, and the chemical composition is characterized by $\mathrm{C}_{41.58} \mathrm{H}_{5.6} \mathrm{O}_{50.85} \mathrm{~N}$ formula. The elemental analysis of biochar found that the calorific value of solid by-product is $11.5 \mathrm{MJ} / / \mathrm{kg}$, which is lower than the MSW fuel with high oxygen content $\mathrm{O} / \mathrm{C}$. The O/C content makes MSW biochar less suitable as fuel but instead can be used in chemical industries or as soil amendment. It is worth mentioning that the biochar produced is suitable for carbon sequestration or long term storage $\mathrm{CO}_{2}$ for green house climate change [33].

\subsection{The Non-Condensable Gases Yields}

The yield and composition of the products evolved in function of the temperature, pressure, and gas composition $\left(\mathrm{CO}, \mathrm{CO}_{2}, \mathrm{CH}_{4}\right.$, and $\left.\mathrm{H}_{2}\right)$ during the de-volatilization. Moreover, the most common gases produced from the process at temperature of $500{ }^{\circ} \mathrm{C}$ are shown in Table 6. The highest fraction of the gaseous components (SynGas) was coming from the $\mathrm{CO}$, followed by the $\mathrm{CO}_{2}$. These results are very promising and show good quality of SynGas due to the high heat of combustion for CO. The SynGAs could be combusted and generated extra heat for the system. However, the methane ratio was low compared to other gases. Maximizing methane ratio in the SynGas is somehow difficult due to the need for hydration step and requires an additional reaction mechanism compared to $\mathrm{CO}$ and $\mathrm{CO}_{2}$ formation.

Table 6. Composition and heat of combustion of gaseous components (SynGas) with error less than $2 \%$.

\begin{tabular}{cccc}
\hline Gas Component & $\begin{array}{c}\text { Gas Yield } \\
\text { (kg/kg MSW) }\end{array}$ & $\begin{array}{c}\text { Heat of Combustion } \\
\text { (kJ/mol) }\end{array}$ & $\begin{array}{c}\text { Normalized Mole } \\
\text { Ratio }\end{array}$ \\
\hline $\mathrm{CO}_{2}$ & 24.7001 & 0 & $22.87 \%$ \\
$\mathrm{CO}$ & 87.21 & 283 & $4.04 \%$ \\
$\mathrm{CH}_{4}$ & 5.6275 & 889 & $5.21 \%$ \\
$\mathrm{H}_{2}$ & 9.515 & 286 & $8.81 \%$ \\
\hline
\end{tabular}

\subsection{FTIR Analysis for MSW Bio-Oil}

The FTIR spectroscopy is used to analyze the pyrolysis bio-oil to determine the basic functional groups. The spectra for FTIR are shown in Figure 3.

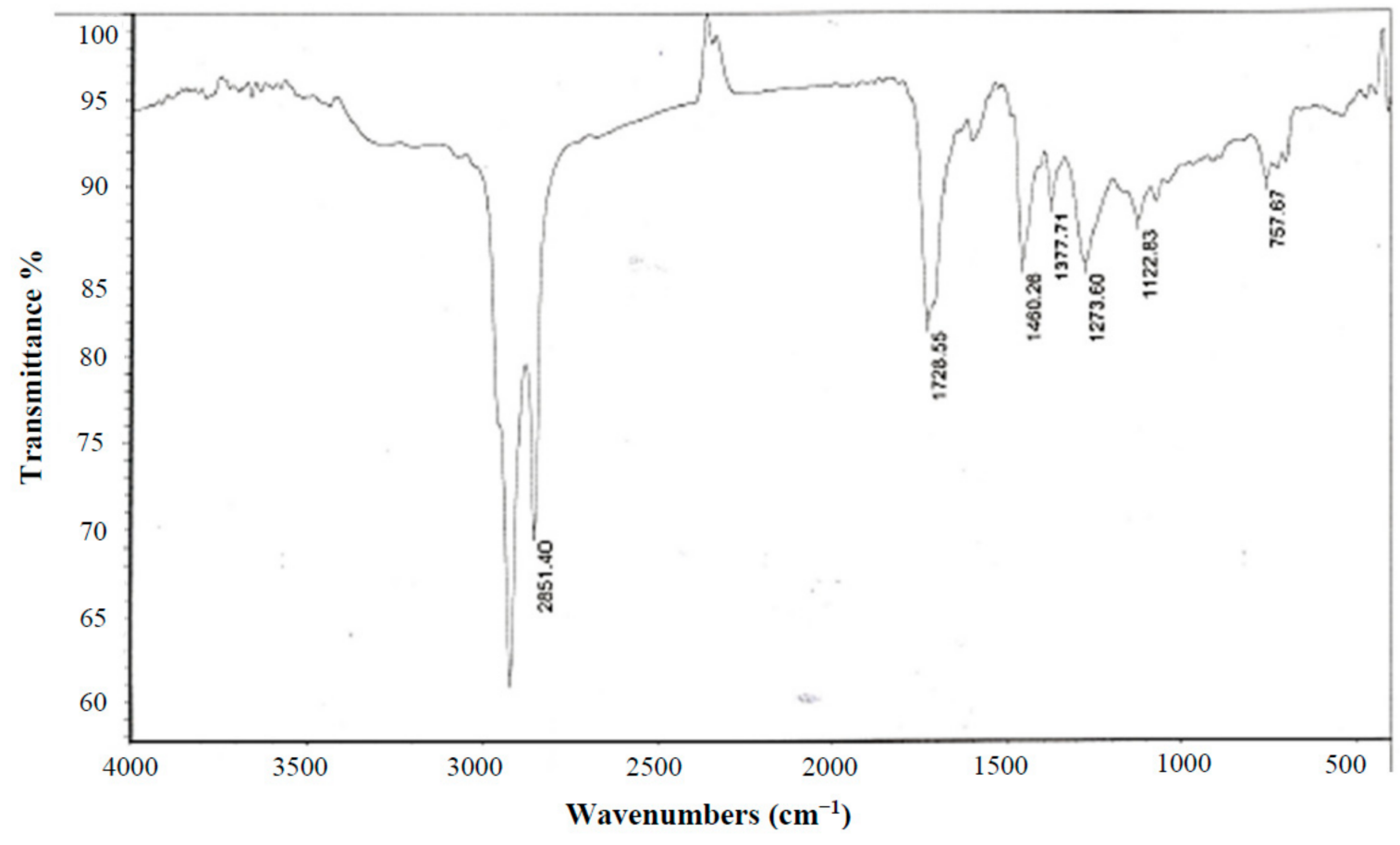

Figure 3. FTIR analysis of MSW pyrolysis bio-oil. 
The FTIR spectrum absorption peaks of MSW biofuel sample are shown in Table 7 . The highest absorption is observed at $2851.4 \mathrm{~cm}^{-1}$, which is attributed to high concentration of hydrocarbon stretching group $(\mathrm{C}-\mathrm{H})$. The lower peak at $1728.55 \mathrm{~cm}^{-1}$ refers to the existence of $\mathrm{C}=\mathrm{O}$ stretch carbonyl compounds, but with less concentration than $(\mathrm{C}-\mathrm{H})$ stretching hydrocarbon compound.

Table 7. FTIR results and functional group composition of MSW pyrolysis biofuel.

\begin{tabular}{|c|c|c|c|}
\hline Frequency $\left(\mathrm{cm}^{-1}\right)$ & Frequency Range $\left(\mathrm{cm}^{-1}\right)$ & Group & Class of Compound \\
\hline 2851.4 & $2935-2915 / 2865-2845$ & C-H asym./sym. stretch & Alkenes: methyl C-H asym./sym. stretch \\
\hline 1728.55 & $1740-1725 /(2800-2700)$ & $\mathrm{C}=\mathrm{O}$ Stretch & Carbonyls: aldehyde (rcho) \\
\hline 1428.55 & $1610-1550 / 1420-1300$ & $\mathrm{C}-\mathrm{C}$ stretch in ring & Carbonyls: carboxylate (carboxylic acid salt) \\
\hline 1460.26 & $1510-1450$ & $\mathrm{C}=\mathrm{C}-\mathrm{C}$ & Aromatic ring stretch \\
\hline 1377.71 & $1420-1370 / 1200-1180$ & C-H rock & $\begin{array}{c}\text { Alkanes: methyl }\left(-\mathrm{CH}_{3}\right) \text { methyl C-H } \\
\text { asym./sym. Bend }\end{array}$ \\
\hline 1273.6 & $640-1620 / 1285-1270$ & C-H Wag $\left(-\mathrm{CH}_{2} \mathrm{X}\right)$ & Organic nitrates \\
\hline 1122.83 & 2260-2240/1190-1080 & C-N stretch & $\begin{array}{l}\text { Aliphatic amines: cyanate (-ocn and c-ocn } \\
\text { stretch) }\end{array}$ \\
\hline 757.67 & $810-750 / 900-860$ & $=\mathrm{C}-\mathrm{H}$ & $\begin{array}{l}\text { Alkanes: Aromatic ring (aryl) group: } \\
\text { 1,2-disubstitution (ortho) }\end{array}$ \\
\hline
\end{tabular}

The peaks at $1428.55 \mathrm{~cm}^{-1}, 1460.26 \mathrm{~cm}^{-1}$ refer to the existence of relatively low concentration of carbonyls and aromatic ring groups, respectively. Moreover, the peaks at $1122.83 \mathrm{~cm}^{-1}$ indicate that biofuel contains (C-N) stretching aliphatic amines group, which mostly refers to lipids and fatty acids. The peak at $757.67 \mathrm{~cm}^{-1}$ indicates to the existence of aromatic ring alkanes.

FTIR analysis of MSW fuel shows that alkanes, alkenes, and carbonyl groups are the main characteristics of MSW oil, which is mainly due to high organic contents of MSW. The aromatic compounds indicate high oxygenation. The presence of C-H groups in alkanes compounds, and $\mathrm{C}=\mathrm{C}$ groups in aromatic, indicates that the liquids have high potential to be used as fuel. The aromatic rings provide chemicals with high added value if the pyrolysis operator decided to distill all the products as utilize the bio-oil for chemical sales than fuel. Due to the nature of the camp and the expected funding for such a future project, the main target would be utilizing bio-oil as a fuel source during the wintertime. That might be the best scenario for bio-oil utilization since Jordan suffers from low energy resources and depends on oil imports. This might be a great benefit for the camp in terms of supplying free energy sources while solving the MSW management. In the long term, the adaptation of such a project will provide job opportunities for the inhabitants. Another benefit of the project is to act as a demonstration model for energy recovery from MSW, solving an environmental problem and economic source for the local communities.

\section{Conclusions}

The present study assessed the pyrolysis as a thermal conversion process of MSW for energy recovery. The MSW samples were taken from Zaatari Syrian Refugee Camp. The proximate and elemental analyses were carried out to investigate the physical and chemical characteristics of MSW. The MSW pyrolysis experiments were conducted using FBR, and the products produced were analyzed using elemental analyzer and FTIR. FTIR analysis of MSW fuel showed that the alkenes, alkanes, and carbonyl groups are the main characteristics of MSW oil. The aromatic compounds indicate high oxygenation. The presence of $\mathrm{C}-\mathrm{H}$ and $\mathrm{C}=\mathrm{C}$ indicates that the liquids have good potential for alternative fuel production by pyrolysis. 
Author Contributions: Conceptualization, M.N.S., Z.A.-H. and M.A.-A.; methodology, M.N.S., Z.A.H. and M.A.-A.; software, E.A.A.; validation, E.A.A.; formal analysis, E.A.A.; investigation, E.A; resources, M.N.S., Z.A.-H. and M.A.-A.; data curation, E.A.A. and M.A.; writing, E.A.A., M.N.S., Z.A.-H., M.A.-A. and M.A.; original draft, E.A.A.; preparation, E.A.A.; writing, review and editing, E.A.A., M.N.S., Z.A.-H., M.A.-A. and M.A.; visualization, E.A.A.; project administration, M.N.S., Z.A.-H. and M.A.-A.; funding acquisition, M.N.S. All authors have read and agreed to the published version of the manuscript.

Funding: Deanship of Research, University of Jordan, Amman, Jordan.

Institutional Review Board Statement: Not applicable.

Informed Consent Statement: Not applicable.

Data Availability Statement: Not applicable.

Conflicts of Interest: The authors declare no conflict of interest.

\section{References}

1. Smallbone, A.; Jia, B.; Atkins, P.; Roskilly, A.P. The impact of disruptive powertrain technologies on energy consumption and carbon dioxide emissions from heavy-duty vehicles. Energy Convers. Manag. X 2020, 6, 100030. [CrossRef]

2. Haller, M.Y.; Carbonell, D.; Dudita, M.; Zenhäusern, D.; Häberle, A. Seasonal energy storage in aluminium for 100 percent solar heat and electricity supply. Energy Convers. Manag. X 2020, 5, 100017. [CrossRef]

3. Alkasrawi, M. Development of Simultaneous Saccharification and Fermentation for Production of Ethanol from Softwood; Lund University: Lund, Sweden, 2004; ISBN 91-628-6126-3.

4. Salameh, T.; Tawalbeh, M.; Al-Shannag, M.; Saidan, M.; Melhem, K.B.; Alkasrawi, M. Energy saving in the process of bioethanol production from renewable paper mill sludge. Energy 2020, 196, 117085. [CrossRef]

5. Song, Q.; Zhao, H.; Jia, J.; Yang, L.; Lv, W.; Bao, J.; Shu, X.; Gu, Q.; Zhang, P. Pyrolysis of municipal solid waste with iron-based additives: A study on the kinetic, product distribution and catalytic mechanisms. J. Clean. Prod. 2020, 258, 120682. [CrossRef]

6. Selim, O.M.; Amano, R.S. Co-Pyrolysis of Chicken and Cow Manure. J. Energy Resour. Technol. 2021, 143, 011301. [CrossRef]

7. Espindola, J.; Selim, O.M.; Amano, R.S. Co-Pyrolysis of Rice Husk and Chicken Manure. J. Energy Resour. Technol. 2021, 143, 022101. [CrossRef]

8. Alrabie, K.; Saidan, M.N. A preliminary solar-hydrogen system for Jordan: Impacts assessment and scenarios analysis. Int. J. Hydrog. Energy 2018, 43, 9211-9223. [CrossRef]

9. Al-Addous, M.; Saidan, M.; Bdour, M.; Dalala, Z.; Albatayneh, A.; Class, C.B. Key aspects and feasibility assessment of a proposed wind farm in Jordan. Int. J. Low-Carbon Technol. 2020, 15, 97-105. [CrossRef]

10. Saidan, M.N.; Al-Yazjeen, H.; Abdalla, A.; Khasawneh, H.J.; Al-Naimat, H.; Al Alami, N.; Adawy, M.; Jaber, M.S.; Sowan, N. Assessment of on-site treatment process of institutional building's wastewater. Processes 2018, 6, 26. [CrossRef]

11. Saidan, M.N.; Al-Addous, M.; Al-Weshah, R.A.; Obada, I.; Alkasrawi, M.; Barbana, N. Wastewater Reclamation in Major Jordanian Industries: A Viable Component of a Circular Economy. Water 2020, 12, 1276. [CrossRef]

12. Al-Qodah, Z.; Al-Shannag, M.; Amro, A.; Bob, M.; Bani-Melhem, K.; Alkasrawi, M. Impact of surface modification of green algal biomass by phosphorylation on the removal of copper (II) ions from water. Turk. J. Chem. 2017, 41, 190-208. [CrossRef]

13. Al-Shannag, M.; Al-Qodah, Z.; Nawasreh, M.; Al-Hamamreh, Z.; Bani-Melhem, K.; Alkasrawi, M. On the performance of Ballota Undulata biomass for the removal of cadmium (II) ions from water. Desalination Water Treat. 2017, 67, 223-230. [CrossRef]

14. Saidan, M.N.; Drais, A.A.; Al-Manaseer, E. Solid waste composition analysis and recycling evaluation: Zaatari Syrian Refugees Camp, Jordan. Waste Manag. 2017, 61, 58-66. [CrossRef]

15. Al-Awad, T.K.; Saidan, M.N.; Gareau, B.J. Halon management and ozone-depleting substances control in Jordan. Int. Environ. Agreem. Politics Law Econ. 2018, 18, 391-408. [CrossRef]

16. Khasawneh, H.; Saidan, M.N.; Al-Addous, M. Utilization of hydrogen as clean energy resource in chlor-alkali process. Energy Explor. Exploit. 2019, 37, 1053-1072. [CrossRef]

17. Saidan, M.N. Cross-sectional survey of non-hazardous waste composition and quantities in industrial sector and potential recycling in Jordan. Environ. Nanotechnol. Monit. Manag. 2019, 12, 100227. [CrossRef]

18. Saidan, M.N.; Drais, A.A.; Linton, C.; Hamdan, S. Solid waste characterization and recycling in Syrian refugees hosting communities in Jordan. In Waste Management in MENA Regions; Springer: Cham, Switzerland, 2020; pp. $281-293$.

19. Al-Addous, M.; Saidan, M.N.; Bdour, M.; Alnaief, M. Evaluation of biogas production from the co-digestion of municipal food waste and wastewater sludge at refugee camps using an automated methane potential test system. Energies 2019, 12, 32. [CrossRef]

20. Al-Addous, M.; Alnaief, M.; Class, C.; Nsair, A.; Kuchta, K.; Alkasrawi, M. Technical possibilities of biogas production from olive and date waste in Jordan. BioResources 2017, 12, 9383-9395.

21. Zhang, Z.; Wang, Q.; Li, L.; Xu, G. Pyrolysis characteristics, kinetics and evolved volatiles determination of rice-husk-based distiller's grains. Biomass Bioenergy 2020, 135, 105525. [CrossRef] 
22. Abdallah, R.; Juaidi, A.; Assad, M.; Salameh, T.; Manzano-Agugliaro, F. Energy Recovery from Waste Tires Using Pyrolysis: Palestine as Case of Study. Energies 2020, 13, 1817. [CrossRef]

23. Slorach, P.C.; Jeswani, H.K.; Cuéllar-Franca, R.; Azapagic, A. Assessing the economic and environmental sustainability of household food waste management in the UK: Current situation and future scenarios. Sci. Total Environ. 2020, 710, 135580. [CrossRef]

24. Withanage, S.; Dias, G.; Habib, K. Review of household food waste quantification methods: Focus on composition analysis. J. Clean. Prod. 2020, 123722. [CrossRef]

25. Patel, A.; Hrůzová, K.; Rova, U.; Christakopoulos, P.; Matsakas, L. Sustainable biorefinery concept for biofuel production through holistic volarization of food waste. Bioresour. Technol. 2019, 294, 122247. [CrossRef]

26. Malika, A.; Jacques, N.; Fatima, B.; Mohammed, A. Pyrolysis investigation of food wastes by TG-MS-DSC technique. Biomass Convers. Biorefinery 2016, 6, 161-172. [CrossRef]

27. Qiu, S.; Zhang, S.; Zhou, X.; Zhang, Q.; Qiu, G.; Hu, M.; You, Z.; Wen, L.; Bai, C. Thermal behavior and organic functional structure of poplar-fat coal blends during co-pyrolysis. Renew. Energy 2019, 136, 308-316. [CrossRef]

28. Tang, Y.; Huang, Q.; Sun, K.; Chi, Y.; Yan, J. Co-pyrolysis characteristics and kinetic analysis of organic food waste and plastic. Bioresour. Technol. 2018, 249, 16-23. [CrossRef]

29. Hu, X.; Guo, H.; Gholizadeh, M.; Sattari, B.; Liu, Q. Pyrolysis of different wood species: Impacts of C/H ratio in feedstock on distribution of pyrolysis products. Biomass Bioenergy 2019, 120, 28-39. [CrossRef]

30. Luo, S.; Xiao, B.; Hu, Z.; Liu, S.; Guan, Y.; Cai, L. Influence of particle size on pyrolysis and gasification performance of municipal solid waste in a fixed bed reactor. Bioresour. Technol. 2010, 101, 6517-6520. [CrossRef]

31. Shao, D.; Hutchinson, E.J.; Heidbrink, J.; Pan, W.-P.; Chou, C.-L. Behavior of sulfur during coal pyrolysis. J. Anal. Appl. Pyrolysis 1994, 30, 91-100. [CrossRef]

32. Ben, H.; Wu, F.; Wu, Z.; Han, G.; Jiang, W.; Ragauskas, A.J. A comprehensive characterization of pyrolysis oil from softwood barks. Polymers 2019, 11, 1387. [CrossRef]

33. Hawash, S.I.; Farah, J.Y.; El-Diwani, G. Pyrolysis of agriculture wastes for bio-oil and char production. J. Anal. Appl. Pyrolysis 2017, 124, 369-372. [CrossRef] 